\title{
Making research and evaluation more relevant and useful in the real world: favoured solutions and uncomfortable realities
}

Nicholas Mays

From Health Services Research: Evidence-based practice

London, UK. 1-3 July 2014

There has been a recent upsurge of advocacy from trialists and policy 'modernisers' for far more use of RCTs as the basis for health and wider public policy. This is exemplified by the UK Cabinet Office's report 'Test, Learn, Adapt' (2012). Mainstream policy makers are now being told that they should make policy by experimenting like scientists. Drawing on experience as an applied health services researcher and policy adviser in government, I will attempt to stimulate reflection on the following questions: how can we explain the timing of this phenomenon; how realistic and helpful is it; and where does it leave the contribution of evaluation in policy?

Published: 7 July 2014

doi:10.1186/1472-6963-14-S2-01

Cite this article as: Mays: Making research and evaluation more

relevant and useful in the real world: favoured solutions and

uncomfortable realities. BMC Health Services Research 2014 14(Suppl 2):01.

London School of Hygiene \& Tropical Medicine, UK

Submit your next manuscript to BioMed Central and take full advantage of:

- Convenient online submission

- Thorough peer review

- No space constraints or color figure charges

- Immediate publication on acceptance

- Inclusion in PubMed, CAS, Scopus and Google Scholar

- Research which is freely available for redistribution 